\title{
Multipl Skleroz Hastalarının Atak ve Atak Dışı Dönem Bulgularının Karşılaştırılması
}

\author{
Meral BOZ SEFEROĞLU ${ }^{1}$, Nizameddin KOCA ${ }^{2}$ \\ 1 SBÜ Bursa Yüksek İhtisas SUAM, Nöroloji Kliniği, Bursa. \\ 2 SBÜ Bursa Yüksek İhtisas SUAM, İç Hastalıkları Kliniği, Bursa.
}

\section{ÖZET}

Multipl skleroz (MS) atağında klinik bulguların ortaya çıkmasına neden olan ileti kayıplarının; myelin kaybı ve hasarlanması sonucu olabileceği gibi, otoimmünkaskadları aktive eden maddelerin aksonal iletkenliği etkilemesiyle de ortaya çıkabileceği düşünülmektedir. Ortaya çıkan inflamatuar süreçlerin yalnızca bir kısmı bulgu vermekte ve atak olarak kliniğe yansımaktadır. İnflamatuar değişikliklerin yoğun görüldüğü atak döneminde hastaların serumlarında da bu değişikliklerin yansımaları görülebilmektedir. Bu çalışmada, MS hastalarının atak döneminde ve atak dışı dönemdeki laboratuvar bulgularını karșılaştırmayı amaçladık. Hem atak döneminde hem de atak dışı dönemde karaciğer fonksiyon testleri, lipit parametreleri, D vitamini düzeyleri, tiroid fonksiyon testleri, ferritin, folat ve vitamin B12 düzeyleri kayitlı olan, 18-65 yaş aralığında, 61 hastanın verileri retrospektif olarak incelendi. Yaş, cinsiyet, boy, kilo, tanı süresi ve hastalık şiddetini gösteren EDSS (expanded disability status scale) skorları kayıt edilen hastaların atak dönemi ve atak dışındaki verileri karşılaştıııldı. Hastaların atak döneminde ve atak dışı dönemde ölçülen lipid parametreleri, ferritin, folat, vitamin B12 düzeyi ve karaciğer fonksiyon testlerinde anlamlı farklılık saptanmazken hastaların atak döneminde Vitamin D düzeylerinin anlamlı olarak daha düşük, tiroid fonksiyonlarının da yüksek olduğu gözlendi. Hastaların takip sürecinde, kolay ulaşlabilir laboratuvar tetkikleri olan vitamin D, tiroid fonksiyon testleri ve kolesterol seviyelerindeki değişikliklerin hastalık aktivitesi ve atak durumu ile ilgili fikir verebileceği düşünülmektedir. Tiroid hormonunun remiyelinizasyon üzerine olası etkilerini değerlendirecek örneklem sayısının daha fazla olduğu daha spesifik çalışmalara ihtiyaç vardır.

Anahtar Kelimeler: Multiple skleroz. Atak. Vitamin D. Tiroid. Lipid.

Comparison of the Multiple Sclerosis Patients Attack and Non-Attack Period Findings

\begin{abstract}
It is thought that the loss of conduction that causes clinical findings in multiple sclerosis (MS) attack may be the result of loss and damage of myelin, as well as the substances that activate autoimmune cascades affect axonal conductivity. Only some of the inflammatory processes that occur are manifesting and are reflected as an attack. The effects of these changes can also be seen in the serum of the patients during the attack period, when the inflammatory changes are intense. In this study, we aimed to compare the laboratory findings of MS patients during the attack and non-attack periods. The data of 61 patients between 18-65 years of age, who had liver function tests, lipid parameters, vitamin D levels, thyroid function tests, ferritin, folate and vitamin B12 levels studied both during and after the attack, were analyzed retrospectively. The attack period and non-attack data of the patients whose age, gender, height, weight, duration of diagnosis and EDSS (expanded-disability status scale) scores were recorded were compared. There was no significant difference in lipid parameters, ferritin, folate, vitamin B12 levels and liver function tests measured in the attack period and in the non-attack period, while the patients had significantly lower vitamin D levels and high thyroid function tests. VitD, Thyroid function tests and changes in cholesterol levels, which are easily accessible laboratory tests, are thought to give an idea about disease activity and attack status. More specific studies with the greater number of samples are needed to evaluate the possible effects of thyroid hormone on remyelination.
\end{abstract}

Key Words: Multiple sclerosis. Attack. Vitamin d. Thyroid. Lipid.

Geliş Tarihi: 26 Şubat 2020

Kabul Tarihi: 20 Mart 2020

Dr. Nizameddin KOCA

SBU Bursa Yüksek İhtisas SUAM, iç hastalıkları kliniği Tel.: 02242951047

E-posta: nizameddin.koca@sbu.edu.tr
Multipl Skleroz (MS) santral sinir sisteminin sisteminin çoğunlukla genç erişkinleri etkileyen, genetik yatkınlık zemininde ortaya çıkabilen, immün-aracılı inflamatuvar, demiyelinizan, nörodejeneratif bir hastalığıdır. Hastalığın tipik özelliği; santral sinir sisteminde birden fazla lezyona ait klinik belirti ve bulguların ortaya çıkması, zaman içinde klinik bulguların yavaş yavaş kaybolması şeklinde atak ve iyileşmeler ile seyretmesidir. ${ }^{1}$ Atak, akut veya subakut başlangıçlı, günler-haftalar içerisinde en yüksek düzeye ulaşan, sonrasında semptom ve bulgularda değişken derece- 
lerde düzelmenin görüldüğü klinik fonksiyon kayb olarak tanımlanmaktadır. ${ }^{2}$

MS atağında klinik bulguların ortaya çıkmasına neden olan ileti kayıplarının; myelin kaybı ve hasarlanması sonucu olabileceği gibi, otoimmün kaskadları aktive eden maddelerin aksonal iletkenliği etkilemesiyle de ortaya çıkabileceği düşünülmektedir. ${ }^{3}$ Bunlar proenflamatuar sitokinler (interferon $\gamma$, tümör nekroz faktörü $\alpha$ vb.), nitrik oksit veya serum IgG fraksiyonunda bulunan "nöroelektrik bloke edici faktörleri” içerir. Bu maddeler aynı zamanda iyon kanalları ile olası doğrudan etkileşimlerine ek olarak, mitokondriyal fonksiyon veya sinaptik iletime de etki edebilirler. ${ }^{2}$ Ortaya çıkan inflamatuar süreçlerin yalnızca bir kısmı bulgu vermekte ve atak olarak kliniğe yansımaktadır. İnflamatuar değişikliklerin yoğun görüldüğü atak döneminde hastaların serumlarında da bu değişikliklerin yansımaları görülebilmektedir. Bunlardan biri de proenflamatuar hücre ve sitokinleri inhibe eden, antienflamatuar hücre ve sitokinlere ise destek olan potent bir immünomodülatör olan D vitaminidir (VitD). VitD reseptörlerinin immün sistem hücrelerinde yaygın bir biçimde bulunduğu ve intrasellüler VitD reseptörleri aracılığı ile immunostimulan etki oluşturduğu ve antiinflamatuar immün yanıtta ve $\mathrm{T}$ hücre fonksiyonlar1nın regülasyonunda önemli rol aldığı gösterilmiştir. ${ }^{4-6}$

Atak döneminde önemli bir hedef olan myelin kılıfinın \%40'1 sudan oluşurken geri kalanın \%75'i lipitlerden ve \%25’i proteinlerden oluşmaktadır. Deneysel olarak oluşturulan ensefalomyelit modellerinde myelin yıkımı sonucu santral sinir sisteminde kolesterol esterlerinin, sülfatid ve serebrositlerin konsantrasyonlarında artış olduğu, oluşturulan ensefalomyelitin aktif fazında serum kolesterol seviyelerinin de arttığı gösterilmiştir. ${ }^{7}$

Bu çalışmada, MS tanısı ile takip ettiğimiz hastaların serum VitD, kolesterol düzeyleri ve tiroid fonksiyon testlerinin MS atağından nasıl etkilendiğini, atak döneminde ve atak dışı dönemde ölçülen düzeylerini karşılaştırmayı amaçladık.

\section{Gereç ve Yöntem}

McDonald 2010 tanı kriterlerine göre MS tanısı almış, MS polikliniğinde takip ve tedavileri devam etmekte olan hem atak döneminde hem de atak dışı dönemde karaciğer fonksiyon testleri (Aspartat aminotransferaz (AST), Alanin aminotransfeaz (ALT)), lipit parametreleri (total kolesterol, trigliserit, yüksek dansiteli lipoprotein (HDL), düşük dansiteli lipoprotein (LDL)), VitD düzeyleri, tiroid fonksiyon testleri (Tiroid stimule edici hormon (TSH), serbest $\mathrm{T}_{4}\left(\mathrm{sT}_{4}\right)$, serbest $\mathrm{T}_{3}$ $\left(\mathrm{sT}_{3}\right)$ ), ferritin, folat ve vitamin $\mathrm{B} 12$ düzeyleri kayıtlı olan, 18-65 yaş aralığında, 61 hastanın verileri retrospektif olarak incelendi. Nöroloji hekimi tarafindan 24 saatten uzun ve bir aydan kisa süren nörolojik belirti- leri olan hastalar klinik atak olarak kabul edildi ve bu süreçte bakılan tetkikleri değerlendirmeye alınd1. Hastaların yaş, cinsiyet, boy, kilo, tanı süresi ve hastal1k şiddetini gösteren EDSS (expanded-disability status scale) skorları kayıt edildi.

Diabetes mellitus, lipit metabolizma bozukluğu, tiroid hastalığı, karaciğer ve renal hastalık tanısı olan ve bu tanılara yönelik tedavi verilen hastalar ile VitD replasmanı alan hastalar çalışmaya dahil edilmedi. Hastaların atak sırasında elde edilen verileri atak dışı verileri ile karşılaştırıldı.

\section{İstatiksel yöntem}

$\mathrm{Bu}$ çalışmada istatistiksel analizler SPSS 22 paket program ile yapılmıştır. Sürekli değişkenlerin dağılımı Kolmogorov-Smirnov veya Shapiro-wilk testleri ile değerlendirildi. Nitel verilerin karşılaştırılmasında Kikare testi kullanıldı. İkili grupların karşılaştırılmasında normal dağılan bağımsız değişkenler için independent samples t testi, bağımlı değişkenler için paired samples t-testi kullanılırken dağılımı normal olmayan bağımsız değişkenler için mann-whitney u testi, bağımlı değişkenler için Wilcoxon testi kullanıldı. Korelasyon analizinde Pearson ve Spearman testleri kullanıldı. Sonuçlar, anlamlılık $\mathrm{p}<0,05$ düzeyinde değerlendirilmiştir.

\section{Bulgular}

MS polikliniğine Ekim2017-Ekim2019 tarihleri aral1ğında atak döneminde ve atak dışı dönemde başvurusu bulunan toplam 61 hasta (20 erkek, 41 kadın) çalışmaya dahil edildi. Katılımcıların yaşlarının ortalama $36,34 \pm 9,51$ y1l ve hastalık sürelerinin $6,06 \pm 6,02$ yıl (min-max: 1-22 y1l)olduğu gözlendi. Vücut kitle indeksleri 25,66 $\pm 4,59 \mathrm{~kg} / \mathrm{m}^{2}$ olan hastaların EDSS skoru 2,34 $\pm 1,70$ olduğu gözlendi (Tablo I).

Tablo I. Hastaların karakteristikleri

\begin{tabular}{|lc|}
\hline & Mean \pm SS \\
\hline Cinsiyet (Kadın/Erkek) & $41 / 20$ \\
Yaş (yı) & $36,34 \pm 9,51$ \\
Boy $(\mathrm{cm})$ & $164,72 \pm 7,72$ \\
Kilo $(\mathrm{kg})$ & $69,42 \pm 11,91$ \\
VKI $\left(\mathrm{kg} / \mathrm{m}^{2}\right)$ & $25,66 \pm 4,59$ \\
EDSS Skoru & $2,34 \pm 1,70$ \\
Tanı süresi (yıl) & $6,06 \pm 6,02$ \\
\hline SS: standart sapma, VKI: vücut kitle indeksi, EDSS: expanded-disability \\
status scale
\end{tabular}

Hastaların atak döneminde ve atak dışı dönemde ölçülen total kolesterol, trigliserit, HDL, LDL, ferritin, folat, B12 vitamin düzeyi ve karaciğer fonksiyon testlerinde anlamlı farklılık saptanmazken hastaların atak döneminde VitD düzeylerinin anlamlı olarak 


\section{MS Atak ve Atak Dışı Bulguların Karşılaştırılması}

daha düşük, tiroid fonksiyonlarının da yüksek olduğu gözlendi (Tablo II).

Tablo II. Multiple Skleroz hastalarının atak sırasında ve atak dışındaki laboratuvar verilerinin karşılaştırması

\begin{tabular}{|lccc|}
\hline & $\begin{array}{c}\text { Atak sırasında } \\
\mathbf{n}=61\end{array}$ & $\begin{array}{c}\text { Atak dışında } \\
\mathbf{n}=61\end{array}$ & $\mathbf{p}$ \\
\hline Total kolesterol (mg/dL) & $196,08 \pm 57,40$ & $193,97 \pm 48,92$ & 0,867 \\
HDL (mg/dL) & $52,69 \pm 11,32$ & $52,24 \pm 14,16$ & 0,882 \\
LDL (mg/dL) & $112,83 \pm 47,53$ & $115,55 \pm 40,81$ & 0,798 \\
Trig (mg/dL) & $143,72 \pm 97,21$ & $132,26 \pm 88,16$ & 0,602 \\
AST (U/L) & $23,09 \pm 14,09$ & $19,61 \pm 7,13$ & 0,133 \\
ALT (U/L) & $27,38 \pm 23,33$ & $21,69 \pm 14,21$ & 0,150 \\
Vitamin D & $13,82 \pm 7,71$ & $22,64 \pm 14,62$ & $0,002^{*}$ \\
Ferritin (ng/mL) & $68,73 \pm 103,75$ & $57,99 \pm 69,20$ & 0,602 \\
Vitamin B12 (pg/mL) & $355,98 \pm 180,41$ & $425,95 \pm 307,99$ & 0,204 \\
Folat(ng/mL) & $7,29 \pm 3,84$ & $9,01 \pm 4,92$ & 0,098 \\
TSH (mlU/mL) & $2,18 \pm 1,34$ & $1,49 \pm 0,94$ & $0,008^{*}$ \\
sT4 (ng/dL) & $1,20 \pm 0,20$ & $0,95 \pm 0,69$ & $0,039 *$ \\
sT3 (pg/dL) & $3,16 \pm 0,50$ & $2,79 \pm 0,78$ & $0,019 *$ \\
\hline HDL: high-densitylipoprotein, LDL: low-densitylipoprotein, Trig: trigliserit, \\
AST: aspartattransaminaz, ALT: Alanintransaminaz, TSH: tiroidstimüle \\
edici hormon, sT4: serbest T4, sT3: serbest T3, p: probability, *: statisti- \\
calsignificance & & & \\
\hline
\end{tabular}

Hastalık süresi ile atak dönemi ve atak dışı dönemdeki VitD, kolesterol, TSH seviyeleri arasındaki ilişkinin korelasyon analizi ile değerlendirmesinde değişkenler arası anlamlı bir korelasyon gözlenmedi.

\section{Tartışma}

Çalışmamızda, atak dönemindeki hastaların VitD düzeylerinin daha düşük, tiroid fonksiyonlarının daha yüksek olduğu saptand. Diğer yandan lipit düzeyleri açısından atak dönemi ve atak dışı dönem arasında anlamlı fark gözlenmedi.

Yapılan gözlemsel çalışmalardan elde edilen bilgilere göre güneş 1şığı ve diyet ile alınan 25 hidroksivitamin D'nin, MS'in gelişmesi ve atakların önlenmesinde önemli bir çevresel faktör olabileceğini vurgulamaktadır. ${ }^{8}$ Düşük serum VitD düzeylerinin MS gelişimi için bir risk faktörü olduğu ve MS hastalarında atak dönemlerinde remisyon dönemlerine göre serum VitD seviyelerinin daha da düştüğü gösterilmiştir. ${ }^{9,10}$ Son çalışmalar ile güneş 1şığı maruziyeti, dizabilite ve VitD arasındaki ilişki ortaya koyulmuş ve uygun miktardaki VitD desteği ile MS'li hastaların kanlarında antienflamatuar sitokinlerde proliferasyon olduğu gözlenmiştir. ${ }^{6}$ Farklı çalışmalarda da EDSS ile serum VitD seviyeleri arasında negatif korelasyon olduğu raporlanmıştır. ${ }^{9,11}$

Atak aktivitesinin serum VitD seviyesi ile ilişkili olduğu gözlenmektedir. MS hastalarının atak dönemlerindeki serum VitD seviyelerinin remisyon dönemlerindek seviyelerinden anlamlı olarak daha düşük oldu- ğu saptanmış ve yüksek atak oranlarına düşük serum VitD seviyelerinin eşlik ettiği gözlemlenmiştir. ${ }^{8,10} \mathrm{MS}$ hastaları ile yapılan prospektif ve longitudinal bir çalışmada, serum VitD seviyelerindeki her 10 nmol/L'lik artışın, atak riskinde \%9-12'lik bir düşüşe karşılık geldiği gösterilmiştir. ${ }^{11}$ Çalışmamızda benzer şekilde D vitamin düzeyi atak döneminde remisyon dönemine göre daha düşük gözlenmiş ancak toplam atak sayısı ile atak sırasında ve atak dışında ölçülen VitD düzeyleri arasında anlamlı bir korelasyon gözlenmemiştir.

Gelişme sırasında tiroid hormonu oligodendrosit farklılaşmasını artırarak miyelinasyona katkıda bulunmaktadır. Hartley ve ark. ${ }^{12}$ deneysel gliotoksin demiyelinizasyon modellerinde tiroid hormonu ve merkezi sinir sistemine spesifik prodrug olan sobetiromun remiyelinasyonu uyardığını göstermiştir. Otoimmün tiroid hastalıkları MS'e en sık eşlik eden otoimmün hastalıklardır. ${ }^{13}$ Insanlarda yapılan gözlemler, tiroid hormonlarının durumu ile bağışıklık fonksiyonu arasında karmaşık bir etkileşim olduğunu göstermektedir. ${ }^{14}$ Yeni teşhis edilen Hashimoto hastalığı olan hastalarda yapılan bir çalışmada, L-tiroksin tedavisinden sonra yüksek proinflamatuar sitokin seviyelerinin düzeldiği raporlanmıştır. ${ }^{15}$ Dolaşımdaki yüksek proinflamatuar sitokin seviyelerinin L-tiroksin tedavisi kullanmayan kişilerde $\mathrm{sT}_{3}$ konsantrasyonları ile negatif korelasyon gösterdiği bildirilmiştir. Aynı çalışmada, proinflamatuar sitokinlerin dolaşımdaki daha yüksek $\mathrm{sT}_{3}$ konsantrasyonları ile ilişkili olduğu bildirilmiş ve bu durumun indüklenen sitokin üretimi ile başlangıçtaki sitokin seviyelerinin tiroid dokusu üzerindeki etkileri arasındaki tutarsızlık nedeniyle olduğu yorumlanmıştır. ${ }^{16}$ Tiroid hormonlarının anti-inflamatuar ve antioksidan özellikleri deneysel bir çalışmada gösterilmiştir. ${ }^{17}$ Ellibeş ile yetmiş yaş arası sağlıklı bireylerden oluşan başka bir kohortta serum tiroid hormon konsantrasyonları ile inflamasyon belirteçleri arasında pozitif bir korelasyon gözlendiği bildirilmiştir. ${ }^{18}$ Gözlemler arasındaki farklılıklar tüm organizma seviyesinde endokrin ve bağışıklık sistemleri arasındaki etkileşimin karmaşık doğasını göstermektedir. Yapılan çalışmalarda, parathormon, TSH, alkalen fosfataz, kreatinin, klorür, kalsiyum, magnezyum ve fosfor değerleri açısından ataktaki hastalar ile remisyondaki hastalar arasında, ataktaki hastalar ile kontrol grubu arasında ve remisyondaki hastalar ile kontrol grubu arasında istatistiksel olarak anlamlı bir ilişki bulunmadığ1 raporlanmıştır. ${ }^{10,19}$ Çalışmamızda tiroid hormonlarının atak döneminde remisyondaki döneme göre daha yüksek saptanması atak döneminde ortaya çıkan inflamatuar sitokinlerin etkisi olabileceği gibi, inflamatuar sürece karşı immün sistemin bir yanıtı olarak da kabul edilebilir. Atak döneminde normal sınırlar içerisinde olmasına rağmen TSH, sT4 ve sT3 düzeylerinin birlikte yükselmiş olması myelin harabiyetini sınırlandırmak ve onarımı indüklemek amacıyla aktive olan endojen mekanizmaların santral etki ile hormon 
seviyelerinin yükselmesi üzerinde etkili olabileceği de göz önünde bulundurulmalıdır.

Literatür incelendiğinde MS hastalarında EDSS'nin total kolesterol ile korele olduğu ve dizabilite arttıkça kolesterol ve trigliserid seviyelerinin de daha yüksek olarak ölçüldüğü gösterilmiştir ${ }^{20}$. Daha geniş bir örneklem ile yapılan başka bir çalışmada ise total kolesterol ve trigliserid seviyelerinin hem dizabiliteyi göstergesi EDSS ile pozitif korelasyonu olduğu, hem de progresyon hızı arttıkça arttığı, yavaş progresyonu olan hastalarda daha düşük olduğu gösterilmiştir. ${ }^{21}$ Tek atak geçiren MS hastalarının değerlendirildiği bir çalışmada, ortalama kontrast tutan lezyon sayısı ile total kolesterol ve LDL kolesterol seviyeleri arasında anlamlı bir korelasyon saptanmıştır ${ }^{7}$. Başka bir çalışmada MR görüntülemelerinde artan ve/veya genişleyen yeni T2 lezyon sayılarının yüksek LDL ile ilişkili olduğu aynı zamanda yüksek kolesterol seviyelerinin ilk klinik atağını geçirmiş MS hastalarında MR'daki lezyon aktivitesini kötüleştirebileceği şeklinde yorumlanmıştır. $^{22}$ Mevcut çalışmada atak dönemindeki kolesterol seviyeleri ile atak dışı dönemdeki kolesterol düzeyi arasında anlamlı fark olmadığını gözlemledik. Literatürde atak döneminde kontrast tutan lezyonu olanlarda lipid düzeylerinin yüksekliği saptanmıştır. Çalışmamızdaki atak döneminde ve atak dışı dönemde lipid düzeylerinin benzer olarak gözlenmesi, hastaların klinik atak olarak değerlendirilmesi nedeniyle kontrast tutan lezyonlarının varlığının tespit edilememesi ile açıklanabilir. Klinik ve radyolojik olarak atak döneminin değerlendirildiği daha geniş hasta popülasyonunda yapılacak kontrollü çalışmalara ihtiyaç vardır.

\section{Limitasyonlar}

Çalışmamızda hastaların atak anında ve atak dışında MR'daki lezyon sayıları ve kontrast tutulumu incelenmemiştir. Literatürde yapılan çalışmalar daha çok kolesterol düzeyleri ile MR'da yeni gelişen, büyüyen ya da kontrast tutan lezyonlar ilişkilendirilmiştir, bu çalışmamızın bir limitasyonu olarak değerlendirilebilir.

\section{Sonuç}

Aynı hasta grubunda atak dönemi ve atak dışı dönemde VitD, tiroid hormonları ve serum lipit düzeylerinin beraber değerlendirildiği çalışmamızda, atak sırasında VitD değerleri literatür ile uyumlu olarak düşük gözlenirken tiroid fonksiyon testleri atak sırasında anlamlı yüksek bulunmuştur. Kolesterol seviyeleri arasında anlamlı bir fark gözlenmemiştir.

Hastaların takip sürecinde, kolay ulaşılabilir laboratuvar tetkikleri olan VitD ve Tiroid fonksiyon testlerindeki değişikliklerin hastalık aktivitesi ve atak durumu ile ilgili fikir verebileceği düşünülmektedir. Tiroid hormonunun remiyelinizasyon üzerine olası etkilerini değerlendirecek örneklem sayısının daha fazla olduğu daha spesifik çalışmalara ihtiyaç vardır.

\section{Kaynaklar}

1. Dutta, R. and B.D. Trapp, Pathogenesis of axonal and neuronal damage in multiple sclerosis. Neurology, 2007. 68(22 Suppl 3): p. S22-31; discussion S43-54.10.1212/01. wnl.0000275229.13012.32

2. Kalincik, T., Multiple Sclerosis Relapses: Epidemiology, Outcomes and Management. A Systematic Review. Neuroepidemiology, $2015 . \quad 44(4): \quad$ p. $199-$ 214.10.1159/000382130

3. Steinman, L., Immunology of relapse and remission in multiple sclerosis. Annu Rev Immunol, 2014. 32: p. 25781.10.1146/annurev-immunol-032713-120227

4. Cantorna, M.T., Vitamin $D$ and multiple sclerosis: an update. Nutr Rev, 2008. 66(10 Suppl 2): p. S135-8.10.1111/j.17534887.2008.00097.x

5. Sassi, F., C. Tamone, and P. D'Amelio, Vitamin D: Nutrient, Hormone, and Immunomodulator. Nutrients, 2018. 10(11).10.3390/nu10111656

6. Correale, J., M.C. Ysrraelit, and M.I. Gaitan, Immunomodulatory effects of Vitamin D in multiple sclerosis. Brain, 2009. 132(Pt 5): p. 1146-60.10.1093/brain/awp033

7. Giubilei, F., G. Antonini, S. Di Legge, M.P. Sormani, P. Pantano, R. Antonini, M. Sepe-Monti, F. Caramia, and C. Pozzilli, Blood cholesterol and MRI activity in first clinical episode suggestive of multiple sclerosis. Acta Neurol Scand, 2002. 106(2): p. 109-12.10.1034/j.1600-0404.2002.01334.x

8. Smolders, J., O. Torkildsen, W. Camu, and T. Holmoy, An Update on Vitamin $D$ and Disease Activity in Multiple Sclerosis. CNS Drugs, 2019. 33(12): p. 11871199.10.1007/s40263-019-00674-8

9. Smolders, J., P. Menheere, A. Kessels, J. Damoiseaux, and R. Hupperts, Association of vitamin D metabolite levels with relapse rate and disability in multiple sclerosis. Mult Scler, 2008. 14(9): p. 1220-4.10.1177/1352458508094399

10. Soilu-Hanninen, M., M. Laaksonen, I. Laitinen, J.P. Eralinna, E.M. Lilius, and I. Mononen, A longitudinal study of serum 25hydroxyvitamin $D$ and intact parathyroid hormone levels indicate the importance of vitamin $D$ and calcium homeostasis regulation in multiple sclerosis. J Neurol Neurosurg Psychiatry, 2008. 79(2): p. 152-7.10.1136/jnnp.2006.105320

11. Simpson, S., Jr., B. Taylor, L. Blizzard, A.L. Ponsonby, F. Pittas, H. Tremlett, T. Dwyer, P. Gies, and I. van der Mei, Higher 25-hydroxyvitamin $D$ is associated with lower relapse risk in multiple sclerosis. Ann Neurol, 2010. 68(2): p. 193203.10.1002/ana.22043

12. Hartley, M.D., T. Banerji, I.J. Tagge, L.L. Kirkemo, P. Chaudhary, E. Calkins, D. Galipeau, M.D. Shokat, M.J. DeBell, S. Van Leuven, H. Miller, G. Marracci, E. Pocius, T. Banerji, S.J. Ferrara, J.M. Meinig, B. Emery, D. Bourdette, and T.S. Scanlan, Myelin repair stimulated by CNS-selective thyroid hormone action. JCI Insight, 2019. 4(8).10.1172/jci.insight.126329

13. Marrie, R.A., N. Reider, J. Cohen, O. Stuve, P.S. Sorensen, G. Cutter, S.C. Reingold, and M. Trojano, A systematic review of the incidence and prevalence of autoimmune disease in multiple sclerosis. Mult Scler, 2015. 21(3): p. 28293.10.1177/1352458514564490

14. van der Spek, A.H., O.V. Surovtseva, K.K. Jim, A. van Oudenaren, M.C. Brouwer, C. Vandenbroucke-Grauls, P.J.M. Leenen, D. van de Beek, A. Hernandez, E. Fliers, and A. Boelen, Regulation of Intracellular Triiodothyronine Is Essential for Optimal Macrophage Function. Endocrinology, 2018. 159(5): p. 2241-2252.10.1210/en.2018-00053 


\section{MS Atak ve Atak Dışı Bulguların Karşılaştırılması}

15. Marchiori, R.C., L.A. Pereira, A.A. Naujorks, D.L. Rovaris, D.F. Meinerz, M.M. Duarte, and J.B. Rocha, Improvement of blood inflammatory marker levels in patients with hypothyroidism under levothyroxine treatment. BMC Endocr Disord, 2015. 15: p. 32.10.1186/s12902-015-0032-3

16. Rozing, M.P., R.G. Westendorp, A.B. Maier, C.A. Wijsman, M. Frolich, A.J. de Craen, and D. van Heemst, Serum triiodothyronine levels and inflammatory cytokine production capacity. Age (Dordr), 2012. 34(1): p. 195201.10.1007/s11357-011-9220-X

17. Nijampurkar, B., F. Qureshi, N. Jain, T. Banerjee, A. Kumar, and H.S. Parmar, Anti-Inflammatory Role of Thyroid Hormones on Rat Air Pouch Model of Inflammation. Inflamm Allergy Drug Targets, $2015 . \quad$ 14(2): $\quad$ p. 117 24.10.2174/1871528114666160105113342

18. Hodkinson, C.F., E.E. Simpson, J.H. Beattie, J.M. O'Connor, D.J. Campbell, J.J. Strain, and J.M. Wallace, Preliminary evidence of immune function modulation by thyroid hormones in healthy men and women aged 55-70 years. J Endocrinol, 2009. 202(1): p. 55-63.10.1677/JOE-08-0488
19. Kimball, S.M., M.R. Ursell, P. O'Connor, and R. Vieth, Safety of vitamin D3 in adults with multiple sclerosis. Am J Clin Nutr, 2007. 86(3): p. 645-51.10.1093/ajcn/86.3.645

20. Zhornitsky, S., K.A. McKay, L.M. Metz, C.E. Teunissen, and M. Rangachari, Cholesterol and markers of cholesterol turnover in multiple sclerosis: relationship with disease outcomes. Mult Scler Relat Disord, 2016. 5: p. 5365.10.1016/j.msard.2015.10.005

21. Durfinova, M., L. Prochazkova, D. Petrlenicova, Z. Bystricka, K. Oresanska, L. Kuracka, and B. Liska, Cholesterol level correlate with disability score in patients with relapsingremitting form of multiple sclerosis. Neurosci Lett, 2018. 687: p. 304-307.10.1016/j.neulet.2018.10.030

22. Weinstock-Guttman, B., R. Zivadinov, D. Horakova, E. Havrdova, J. Qu, G. Shyh, E. Lakota, K. O'Connor, D. Badgett, M. Tamano-Blanco, M. Tyblova, S. Hussein, N. Bergsland, L. Willis, J. Krasensky, M. Vaneckova, Z. Seidl, and M. Ramanathan, Lipid profiles are associated with lesion formation over 24 months in interferon-beta treated patients following the first demyelinating event. J Neurol Neurosurg Psychiatry, 2013. 84(11): p. 1186-91.10.1136/jnnp-2012304740 
